\title{
Resin flow analysis during RTM Manufacturing of GFRP composites containing embedded impermeable inserts
}

\author{
Análise do fluxo de resina durante a fabricação de compósitos GFRP via RTM contendo insertos \\ impermeáveis embebidos
}

Análisis del flujo de resina durante la fabricación de compuestos de GFRP mediante RTM que contienen insertos impermables incrustados

Received: 04/23/2021 | Reviewed: 05/03/2021 |Accept: 05/08/2021 | Published: 05/22/2021

\author{
Rudá Aranha \\ ORCID: https://orcid.org/0000-0001-9255-1018 \\ Federal University of Campina Grande, Brazil \\ E-mail: rudaaranha@gmail.com \\ Laura Hecker de Carvalho \\ ORCID: https://orcid.org/0000-0003-3118-0123 \\ Federal University of Campina Grande, Brazil \\ E-mail: heckerdecarvalho@yahoo.com.br \\ Wanderley Ferreira de Amorim Junior \\ ORCID: https://orcid.org/0000-0002-4252-0616 \\ Federal University of Campina Grande, Brazil \\ E-mail: engenhariabrasileira1@gmail.com
}

\begin{abstract}
The aim of this work is to analyze resin flow during RTM manufacturing of GFRP composites containing embedded impermeable inserts. High-density polyethylene inserts were embedded in the composites during processing via vacuum assisted resin transfer molding (RTM). The processing station plate was assembled so that digital image analysis of flow during and after processing could be taken. Three-point bending test specimens were cutout from the plates and their fractured surfaces were analyzed by optical fractography. Results indicate the inserts to block transverse resin flow making it difficult to wet the fibers thoroughly, which led to non-uniform plate thickness. Resin rich regions near the sides of the inserts were observed. Three-point bending failure mode analysis showed the occurrence of fiber delamination by type II shear stress, detachment between the fiber/matrix interface and the insert, and fracture of the composite to proceed by crack propagation through the resin rich region.
\end{abstract}

Keywords: Composite materials; RTM; Embedded inserts.

\section{Resumo}

O objetivo deste trabalho é analisar o fluxo de resina durante a fabricação de compósitos GFRP (Glass Fiber Reinforced Polymer) via RTM (Resin Transfer Molding) contendo insertos impermeáveis embebidos. Os compósitos foram processados com inserts impermeáveis de polietileno de alta densidade embebidos via RTM. O sistema de processamento foi montado de forma que a análise digital da imagem do fluxo durante e após o processamento pudesse ser realizada. Amostras para ensaios de flexão em três pontos foram cortadas das placas e suas superfícies fraturadas foram analisadas por fratografia ótica. Os resultados indicam que a presença dos inserts bloquearam o fluxo transversal de resina dificultando o molhamento completo das fibras, o que levou a uma espessura da placa não uniforme. Regiões ricas em resina próximas as laterais dos inserts foram observadas. A análise do modo de falha dos compósitos através do ensaio de flexão em três pontos mostrou delaminação das fibras por tensão de cisalhamento tipo II, descolagem entre a interface fibra/matriz e o insert, e fratura do compósito com propagação da trinca através da região rica em resina.

Palavras-chave: Materiais compósitos; RTM; Inserts embebidos.

\section{Resumen}

El objetivo de este trabajo es analizar el flujo de resina durante la fabricación de composites de GFRP (Polímero Reforzado con Fibra de Vidrio) mediante RTM (Resin Transfer Moulding) que contienen insertos impermeables incrustados. Los compuestos se procesaron con inserciones impermeables de polietileno de alta densidad incrustados mediante RTM. El sistema de procesamiento se configuró para que se pudiera realizar el análisis digital de la imagen de flujo durante y después del procesamiento. Se cortaron de las placas muestras para las pruebas de flexión en tres puntos y se analizaron sus superficies fracturadas mediante fractografía óptica. Los resultados indican que la presencia de los insertos bloqueó el flujo cruzado de resina dificultando que las fibras se humedecieran por completo, lo que condujo a un espesor de placa no uniforme. Se observaron regiones ricas en resina cerca de los lados de los insertos. El 
análisis del modo de falla de los composites a través de la prueba de flexión en tres puntos mostró deslaminación de las fibras por esfuerzo cortante tipo II, despegue entre la interfaz fibra / matriz y el inserto, y fractura del composite con propagación de grietas a través del región rica en resina.

Palabras clave: Materiales compuestos; RTM; Insertos incrustados.

\section{Introduction}

Current demands make the development of specialized materials for specific applications such as multifunctional composites become increasingly necessary and, nowadays, a wide range of engineering materials is available for suiting those needs. One of the ways to produce multi-functional composite materials is by inserting different materials into traditional composites (Lawrence et al., 2007). Inserts serve both to enhance the inherent properties of composites and to add functionality to these materials. Some examples of multifunctional composites would be the use of inserts applied for protection against electromagnetic interference or EMI shielding (Chizari et al., 2017), use of layers of ceramic material for flame applications (Hanu et al., 2004), Composites with inserts of metal for automotive application (Gebhardt and Fleischer, 2014). Hybrid composites, such as those studied by Agnes and Hilling (2020), Souza et al. (2020) and Batista et al. (2020) can be multifunctional depending on the applications. Resin Transfer Molding (RTM) is a well-known manufacturing process of composite materials. It is a liquid molding (LM) process and consists of injecting a liquid resin into a closed mold containing the reinforcing fibrous medium. The steady growth on the production and use of composite materials for several applications renders RTM an excellent alternative processing technique as it not only enhances productivity but also reduces costs.

Lawrence et al. (2007) used computational tools to analyze the resin flow behavior during VARTM (vacuum assisted resin transfer molding) processing of a composite having an embedded insert. They showed that the number of voids in the composite increased with insert dimensions and insert distance from the resin entry point. Jhan et al. (2011) analyzed the flow of resin in sandwich laminates manufactured by VARTM. They observed the phenomenon of race-tracking in both thin and thick structures, which is very important in the calculation of permeability. Obaid et al. (2008) manufactured a multifunctional vinylester/glass fiber composite with embedded copper inserts by RTM and observed an increase in the electrical conductivity of copper inserted samples when compared to samples without inserts. They also found that, when adhesion between the insert and the matrix was good, the mechanical properties of the composites containing inserts were similar to those of composites without them. Kim et al. (2006) studied fatigue and delamination failures in multifunctional Epoxy/ fiberglass composites with embedded copper strips and observed that electrical conductivity was lost when detachment between the insert and the composite occurred. Xiao et al. (2016) studied the behavior of vacuum hot press molded composites having embedded lithium inserts for structural and energy storage purposes. They reported the presence of resin-rich regions near the sides of the inserts, denominated "resin pockets". Pappada et al. (2012) studied the behavior of hybrid composite plates, embedding superelastic shape memory alloy (SMA) wires, subjected to low-velocity impacts. These low-velocity impacts showed an increase of the energy needed for the onset of delaminations and that SMA wires are capable to improve the damage tolerance of glass reinforced laminates, mainly at energies below $10 \mathrm{~J}$. Pappada et al (2012) conclude that SMA wires attenuate the effect of the impact dissipating a fraction of the kinetic energy due to a high internal friction characterizing their crystal structure. Madhi et al. (2003); Lee et al. (2007) and Wang et al. (2013) analyzed the mechanical behavior of different types VARTM processed multifunctional composites having embedded ballistic ceramics for structural and ballistic applications. Madhi et al. (2003) reported that the structural performance of a Composite Integral Armor (CIA) beam is dependent on its manufacturing process. CIA beams fabricated from single step VARTM outperformed beams manufactured by a multi-step process. Lee et al. (2007) observed an improvement in damage tolerance due to reduced delamination, in addition to reduced weight and manufacturing costs when using single-step processing instead of the traditional multi-step processing. Wang et al. (2013) noted that each layer of a VARM processed multi-layer composite had different damage characteristics when subjected to the ballistic test. Naik et al. (2009) evaluated the insert 
assemblies with through-the-thickness compressive loading. Performance of aluminum inserts is compared with that of 3D woven composite inserts. The results showed that specific strength of 3D woven composite inserts is higher than that of aluminum inserts, beyond significant weight saving of material. Ahmed et al. (2010) and Ahmed et al. (2011) analyzed the adhesion properties of sandwich composites having aluminum inserts with different geometries (rectangular, cylindrical and tapered) under flexural loading. It was reported that the failure stress and adhesion properties were dependent on the embedded insert length and geometry. Sandwich composites with tapered inserts showed better load bearing properties compared to rectangular and cylindrical inserts of the same length. The results showed the reduced sandwich stiffness is a function of crack length Ahmed et al. (2010). When leaf inserts were introduced, better adhesion properties were found when compared with other insert geometries Ahmed et al. (2011). Zhao (2011) investigated the properties of Aerosol-Jet printed multifunctional composites with copper inserts, used as sensors with structural characteristics implanted in aircrafts and reported that all the specimens catastrophically fractured. Etches and Fernando (2009) reported on the fabrication and evaluation of extrinsic Fabry-Perot interferometric (EFPI) sensors when embedded in fiber-reinforced composites and tested under quasi-static tensile and compressive mechanical loading. When the composite was subjected to quasi-static tensile loading, the sensors failed around a strain level of $0.5 \%$; under compressive loading, the sensors survived until the failure of the composite at $1.1 \%$ strain. Thakur and Dong (2020) study a way to print multifunctional composite materials with 3D continuous carbon fibers. Continuous carbon fibers were deposit simultaneously with doped functional photopolymer resin utilizing a coextrusion technique. One full lithiumion structural battery was successfully printed in one single step. Each coated carbon fiber acted as a micro-battery cell.

The constant growth in the use of multifunctional composites has rendered necessary the development and/or to adaptation of existing processing techniques. According to Madhi et al. (2003) the use of single step RTM for manufacturing multifunctional composites, reduces processing time compared to the traditional multi step method. This is because in single step RTM, several reinforcing layers are positioned together in the preform and processing is performed in one-step, whereas in traditional RTM each layer is fabricated separately and then brought together with an adhesive. Despite the increasing development of multifunctional composites, few works explore their processing by single step RTM.

The aim of this work is to analyze resin flow during manufacturing of GFRP composite containing embedded impermeable inserts. The plates were fabricated by RTM, resin flow was analyzed via image processing and composite failure mode was observed by three-point bending tests.

\section{Methodology}

In this work a laboratory research was carried out. Six composite plates measuring 250x250x $14 \mathrm{~mm}^{3}$ were manufactured by RTM. The plates were composed of unsaturated polyester resin 10316-10 IBX with viscosity between 250 to $350 \mathrm{cp}$, manufactured by the company IBEX Químicos e Compósitos ltda.; E-glass fiber fabric, with a weight of $600 \mathrm{~g} / \mathrm{m}^{2}$ manufactured by the company Redelease ltda.; and nylon inserts with dimensions of 50x50x4mm. The flowchart in Figure 1 shows the main stages of the manufacturing and analysis of the composites plates processing in this work. 
Research, Society and Development, v. 10, n. 6, e10410615362, 2021

(CC BY 4.0) | ISSN 2525-3409 | DOI: http://dx.doi.org/10.33448/rsd-v10i6.15362

Figure 1 - Steps in the process of manufacturing and analysis of the composite plates.

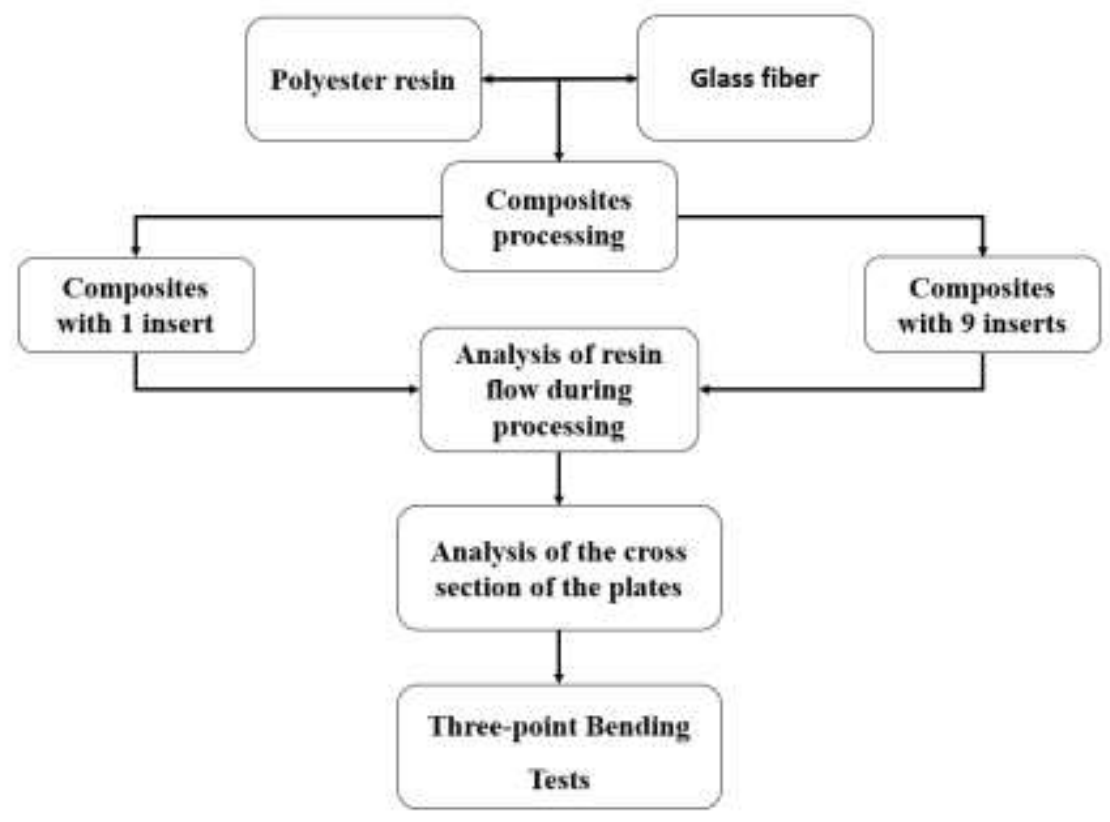

Source: Authors.

The mold is comprised by two rigid surfaces with $13 \mathrm{~mm}$ thick: glass cover and polyethylene base. The vacuum was generated with an EMI 45HER model 1/8 Cv compressor (Aranha, 2017). Figure 2 illustrates the bench system developed, for this work. The system consists of mold, vacuum pump, vacuum gauge, flow control valve and camera support.

Figure 2 - RTM processing system.

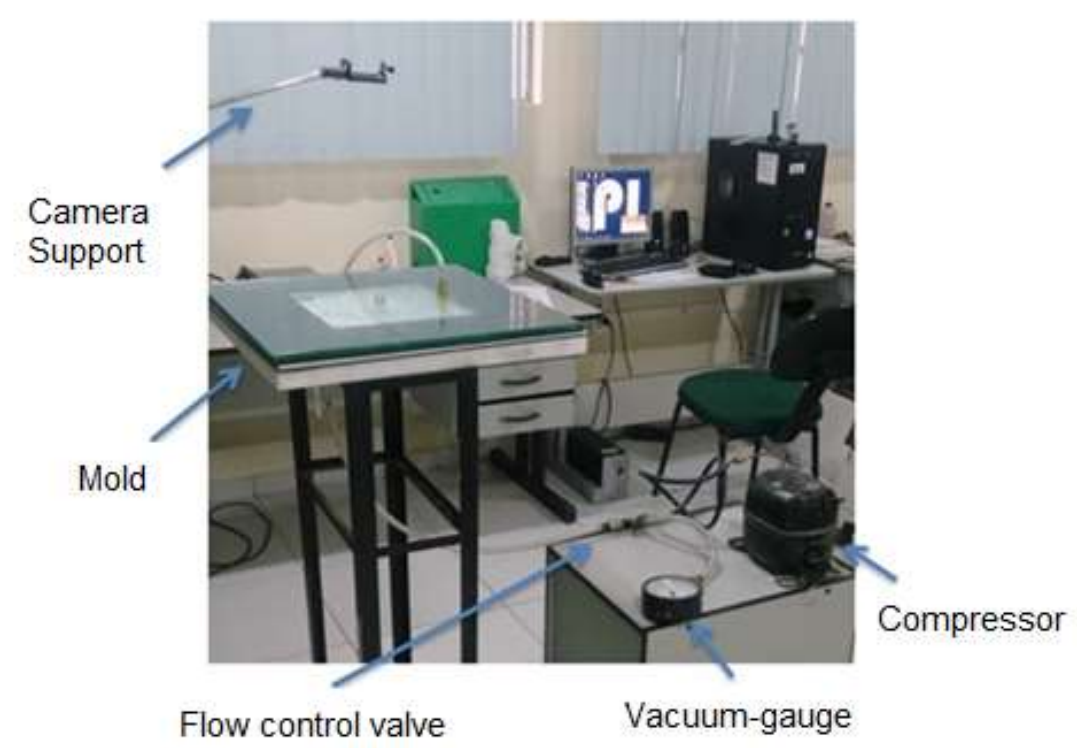

Source: Authors.

Table 1 shows the main plate fabrication variables: number of layers, number of inserts, positive pressure, vacuum pressure, resin inlet points, resin outlet points, and flow type. Figure 3 shows the schematic drawing of the projected mold. The mold (1) consists of a base (2), frame (3) and cover (4). The mold is designed with multiple resin inlets and exit points to be 
versatile in manufacturing plates via RTM. The other numbers highlighted in Figure 3 show the inlet and outlet points used to fabricate the plates, see Table 1.

Figure 3 - Placement of resin inlet and outlet for RTM processing of the composites.

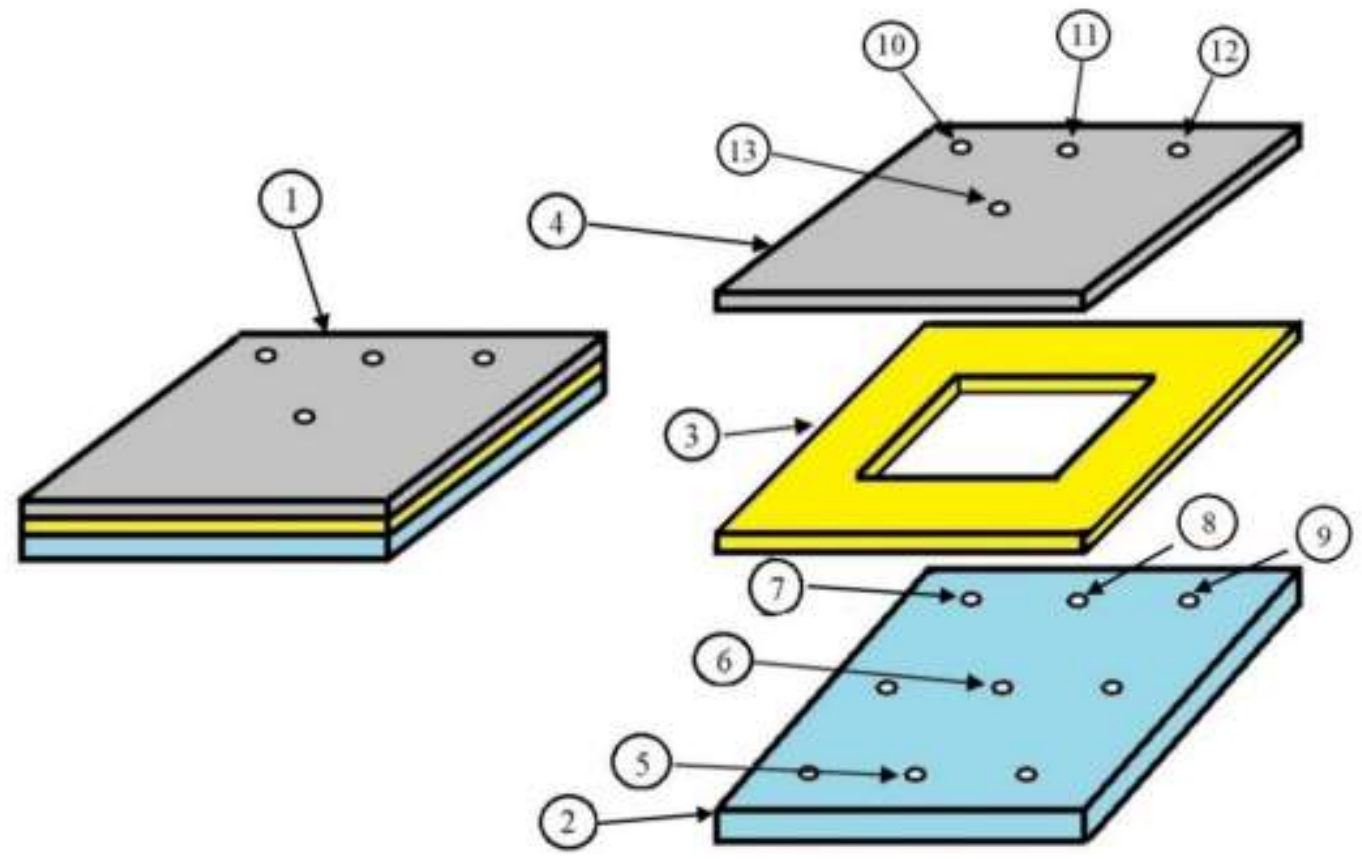

Source: Authors.

Table 1 - Main variables of the plates manufactured.

\begin{tabular}{cccccccc}
\hline Plate & $\begin{array}{c}\mathrm{N}^{\mathbf{o}} \text { of } \\
\text { layers }\end{array}$ & $\begin{array}{c}\mathrm{N}^{\mathbf{o}} \text { of } \\
\text { inserts }\end{array}$ & Inlet Pressure & $\begin{array}{c}\text { Outlet } \\
\text { Pressure }\end{array}$ & $\begin{array}{c}\text { Inlet } \\
\text { location* }\end{array}$ & $\begin{array}{c}\text { Outlet } \\
\text { location(s)* }\end{array}$ & Flow \\
\hline P01 & 16 & 1 & $1,01325 \mathrm{bar}$ & $0.8 \mathrm{bar}$ & $(5)$ & $(8)$ & linear \\
P02 & 14 & 1 & $1,01325 \mathrm{bar}$ & $0.5 \mathrm{bar}$ & $(5)$ & $(7),(8),(9)$ & linear \\
P03 & 10 & 9 & $1,01325 \mathrm{bar}$ & $0.4 \mathrm{bar}$ & $(5)$ & $(7),(8),(9)$ & linear \\
P04 & 10 & 9 & $1,01325 \mathrm{bar}$ & $0.4 \mathrm{bar}$ & $(6)$ & $(13)$ & radial \\
P05 & 10 & 9 & $1,01325 \mathrm{bar}$ & $0.4 \mathrm{bar}$ & $(5)$ & $(10),(11),(12)$ & linear \\
P06 & 10 & 9 & $1,01325 \mathrm{bar}$ & $0.4 \mathrm{bar}$ & $(5)$ & $(10),(11),(12)$ & linear \\
\hline
\end{tabular}

*The numbers refer to the points highlighted in Figure 3. Source: Authors.

Figure 4 shows the positions of the inserts placed at the center of the mold. Figure 4a illustrates the preform with a single insert; Figure $4 \mathrm{~b}$ illustrates the preform with nine inserts and Figure $4 \mathrm{c}$ illustrates the preform with nine inserts held in place with a fixing screen to prevent them from moving during processing. In Figures $4 \mathrm{~b}$ and $4 \mathrm{c}$ it is possible to see pieces of rubber used for uniform separation of the inserts (1mm) as used by Madhi et al. (2003). In Figure $4 \mathrm{c}$ the rubber pieces used were smaller. 
Figure 4 - Insert pleacement in the prefrom: (a) preform with one insert; (b) preform with nine inserts;(c) inserts placed on a fixing screeen to avoid movement during processing.

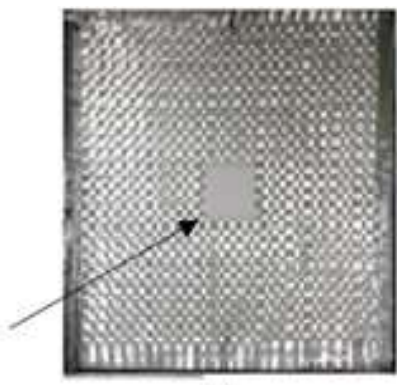

a)

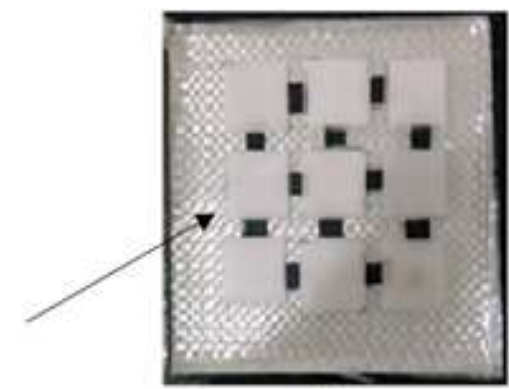

b)

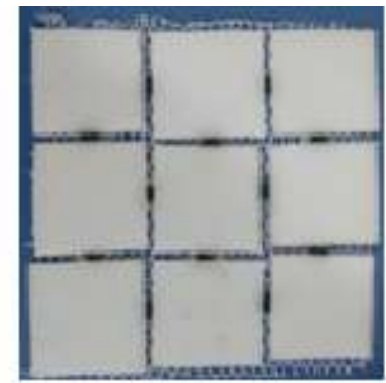

c)

Source: Authors.

ASTM D7264 flexural test samples having 152x13x14 mm were cut out from the plates with a disk saw at Stratus Aeronaves (Figure 5). Three-point bending tests were performed to analyze the failure modes of the composites. The tests were performed on a $50 \mathrm{kN}$ load cell SHIMADZU AGS-X universal testing machine belonging to NUTES/UEPB with $132 \mathrm{~mm}$ support span and $1 \mathrm{~mm} / \mathrm{min}$ displacement rate.

Figure 5 - Sample cutting plan.

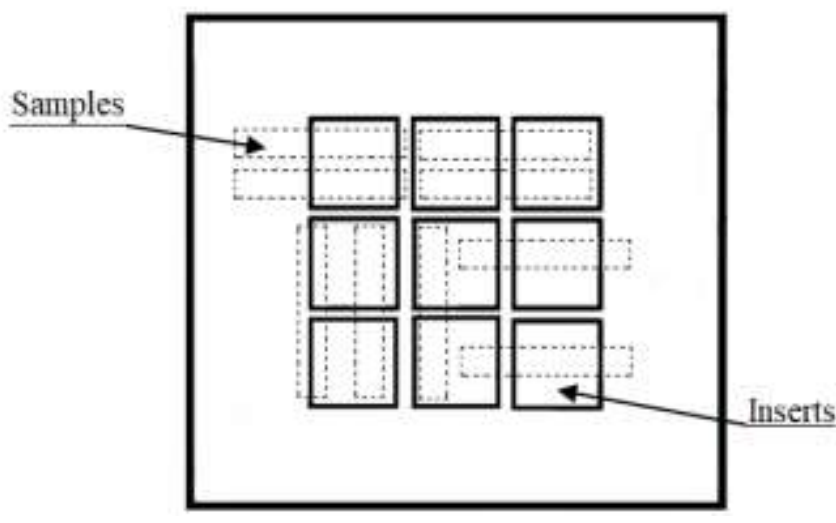

Source: Authors.

\section{Results and Discussion}

\section{Plates with a single embedded insert (P01 and P02)}

Figure 6 illustrates the resin flow into the mold during processing of plate P01 described in Table 1. The inlet and outlet were positioned at points (1) and (2), respectively (Figure 6a). The flow took place from the edges to the center of the mold, points (3), (4), (5) and (6), evidencing the difficulty of the resin to flow through the preform (Figures 6b-f). It is believed that this difficulty is due to the low porosity of the preform. Similar results have been reported by Sozer et al. (2012) and Hammami et. al. (1998), where a race track was observed on the mold walls. 
Figure 6 - Resin flow during RTM processing on composite plate P01 at different processing times: (a) 0s, (b) 60s, (c) 120s, (d) $180 \mathrm{~s}$, (e) $240 \mathrm{~s}$ (f) $2179 \mathrm{~s}$ (end of process).

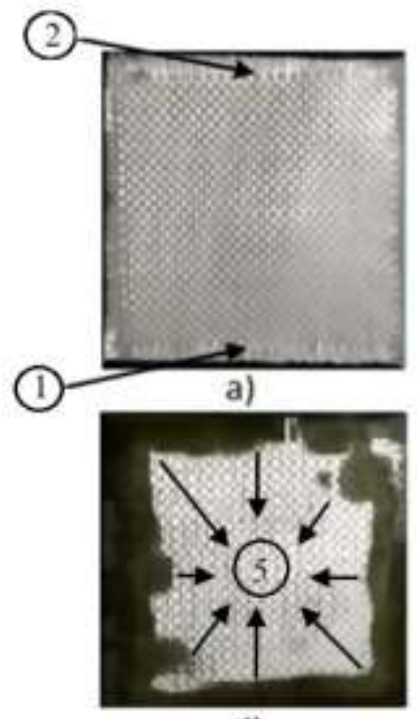

d)

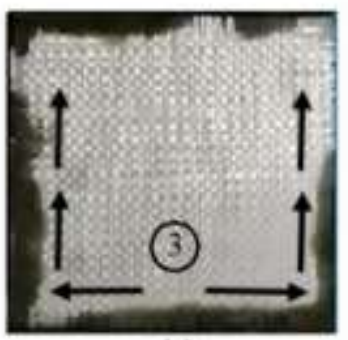

b)

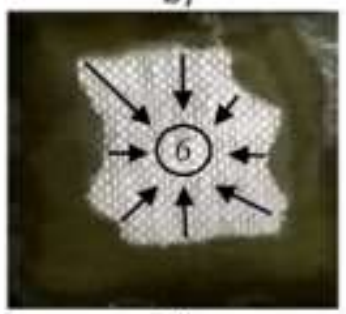

e)

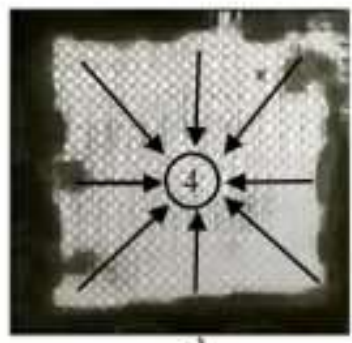

c)

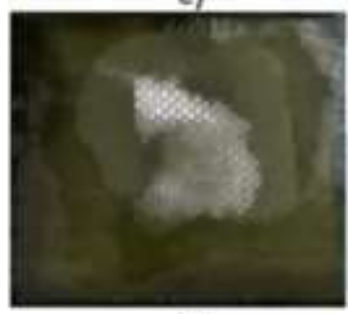

f)

Source: Authors.

Figure 7 illustrates plate $\mathrm{P} 01$ at the end of curing showing a dry region in the center of the plate (1), which confirms that resin flow through the preform was not possible (Figure 7a).

Figure 7 - Plate P01: (a) top view with dry spots; (b) bottom view showing resin flow.

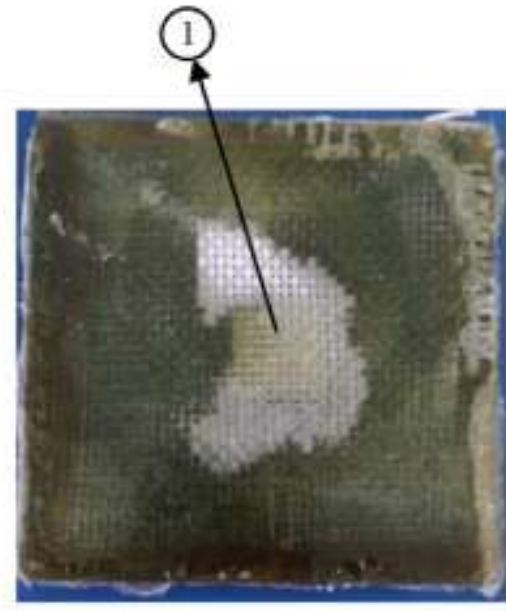

a)

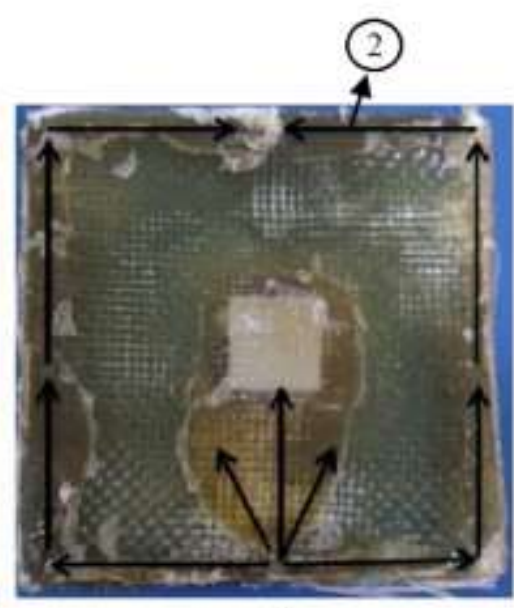

b)

Source: Authors.

Figure $7 \mathrm{~b}$ confirms that flow occurred through the mold edges, with intense race-tracking (2). It is believed that dry spot formation results from the low porosity of the preform. According to Amorim Jr. (2007) and Chen et al. (2008), low preform porosity is associated to the excessive number of layers, the nest phenomenon and layer compression by vacuum pressure. Another hypothesis for the dry spot observed was that the injection/outlet layout used in that plate (1 injection inlet and 1 outlet) was not effective in removing air from the mold. Liu et al. (1996) states that resin flow can branch and cure in 
areas of low permeability, leading to dry zones. The presence of inserts, ribs, nuclei or heterogeneities in the preform enhance this possibility.

Figure 8 shows the resin flow inside the mold during processing of plate P02. In order to avoid the problems previously encountered on plate P01, some modifications were made for processing plate P02. These modifications included decreased number of preform layers, increased vacuum pressure and changes in injection lay-up with 1 inlet (1) and 3 outlet (2) points (Figure 8a). All other processing parameters remained as in plate P01. Figure 8b shows that the flow did not occur from the edge to the center of the plate (3), as in plate P01. Figures 8c, 8d, 8e and 8f shows a dry-spot region on the top of the insert (4). The formation of this dry region indicates the insert blocked resin flow. This result agrees to that reported by Lawrence et al. (2007).

Figure 8 - Resin flow during processing of plate P02 at (a) 0s, (b) 60s, (c) 120s, (d) 180s, (e) 240s (f) 1010s (end of process).

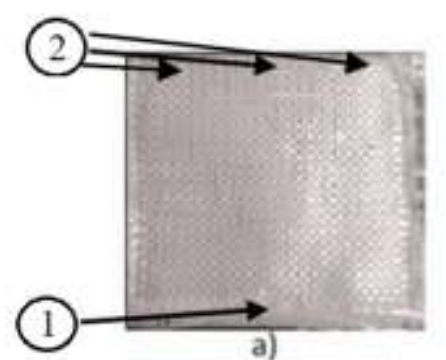

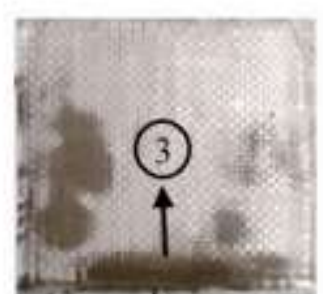

b)

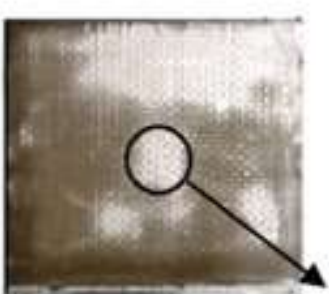

c)

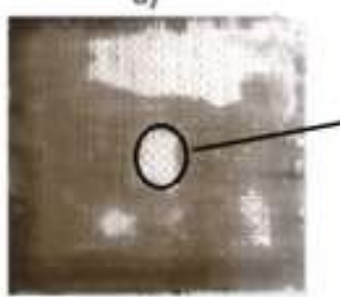

d)

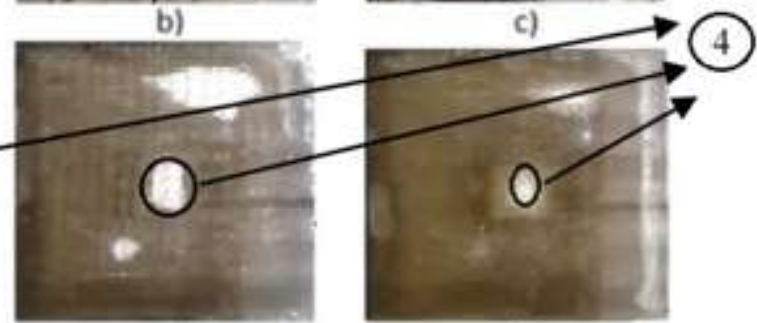

e) f)

Source: Authors.

\section{Plates with nine embedded inserts (P03, P04, P05 e P06)}

Figure 9a-f, illustrates the resin flow inside the mold during processing of plate P03. Plate P03 has nine embedded inserts, the same inlet/outlet, (1) and (2), scheme as plate P02, a lower number of preform layers with respect to plates P01 and P02, and lower vacuum injection pressure (0.4 bar compared with 0.5 bar for plate P02 or 0.8 bar for plate P01).

Despite the lower number of layers, flow occurred from the edges to the center of the plat (3), which was attributed to the higher number of inserts in this plate (Figures 9b, 9c, 9d). Figure 9e shows that after 240s, the resin begins to flow through the preform (4). Figure 9f shows that resin flow through the inserts was blocked and that, in addition, flow occurred through the channels formed between the inserts (5) and that a dry spot region was formed at the center of the plate (6). 
Figure 9 - Resin flow during processing of plate P03 at (a) 0s, (b) 60s, (c) 120s, (d) 180s, (e) 240s (f) 390s (end of process).

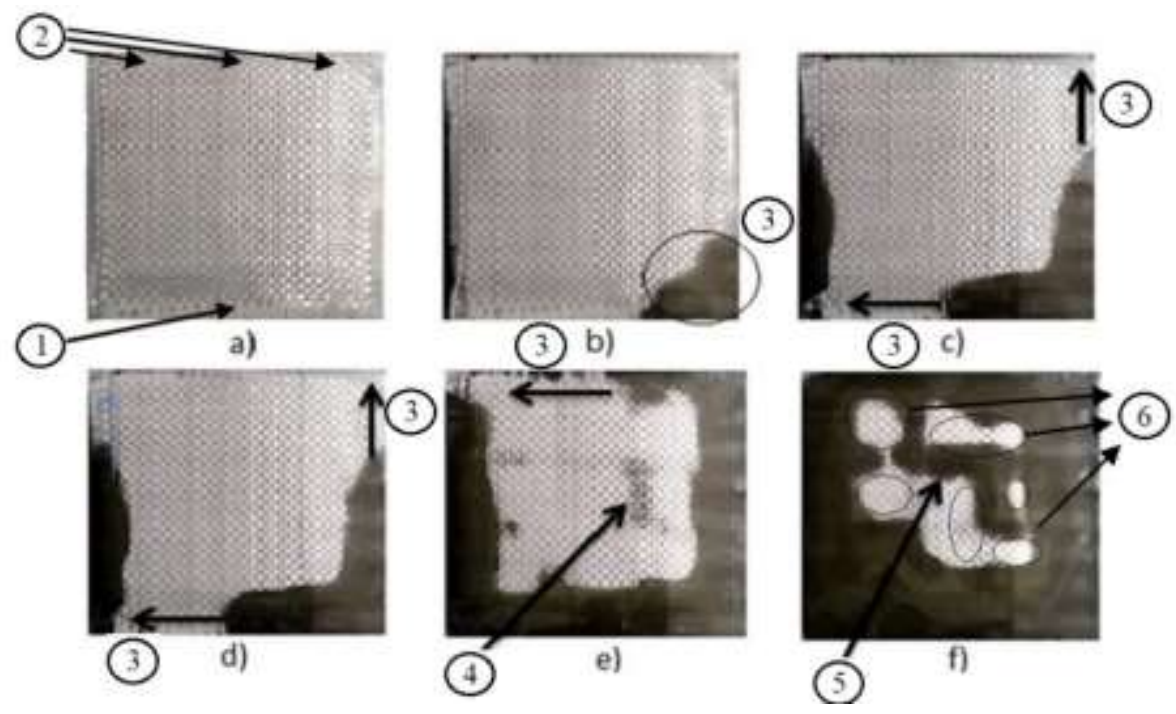

Source: Authors.

Figure 10 shows a processing schematic for plate P03 where the internal flow and the types of flow that exist during processing. According to Lawrence et al. (2007), there are two main types of internal flow: lateral flow and transverse flow (Figure 10a). The addition of inserts tends to block transverse flow and thus, lateral flow becomes solely responsible for wetting the fibers above the inserts. The lateral flow alone cannot wet the fibers located above the inserts (Figure 10b), resulting in the formation of the dry spot shown in Figure 8f.

Figure 10 - Scheme showing the kinds of flow that occur during processing.

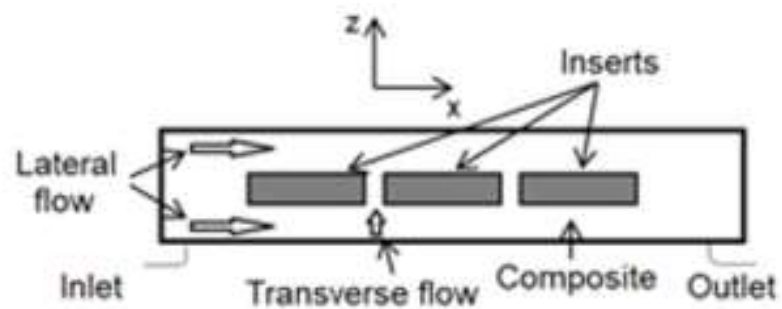

a)

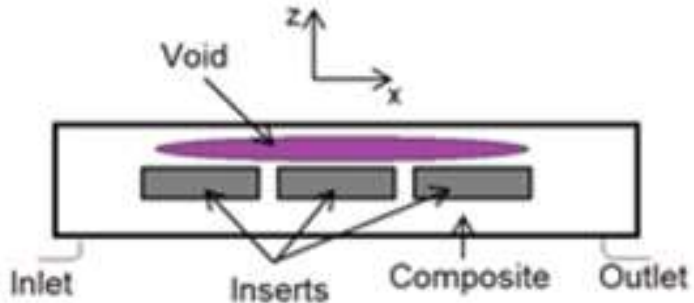

b)

Source: Authors.

In an attempt to solve the problems encountered on plate P03, injection lay-up changes were performed on plate P04. Inlet and outlet points were placed opposite to each other in different planes. The inlet was located on the mold base and the outlet was located on the mold cover ( 1 inlet and 1 outlet in the center of the mold). This set up let do a change in flow. Rather than having a linear flow, in which inlet and outlet are placed opposite to each other in different faces of the mold, this new set up generates a radial flow.

Figure 11a-f shows the resin flow inside the mold during processing of plate P04. Flow takes the shape of an ellipse until it reaches the walls of the mold, as described by Gauvin et al. (1996). 
Figure 11 - Resin low during processing of plate P04 at (a) 0s, (b) 60s, (c) 120s, (d) 180s, (e) 240s (f) 485s (end of process).

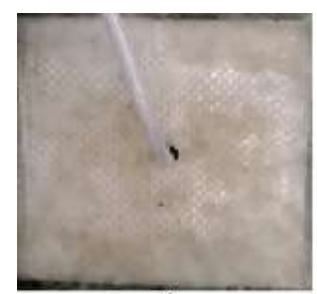

a)

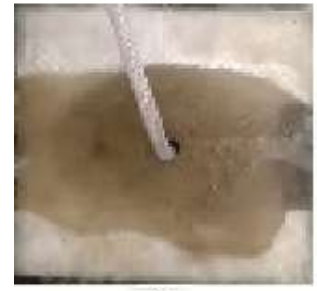

d)

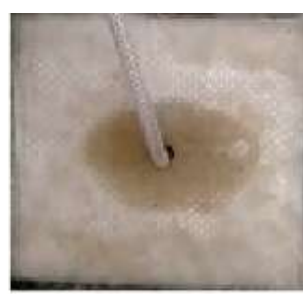

b)

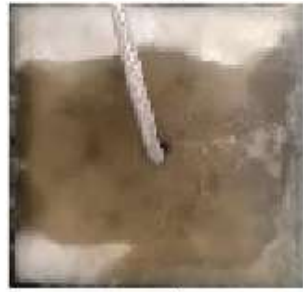

e)

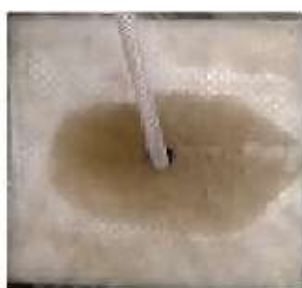

c)

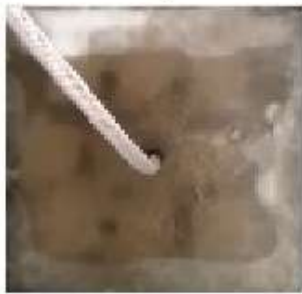

f)

Source: Authors.

Figure 12 illustrates plate P04 after processing. It was found that the changes prevented the formation of dry spots on the plate surface.

Figure 12 - Insert movement in plate P04 caused by inlet and outlet points at opposing mold surfaces.

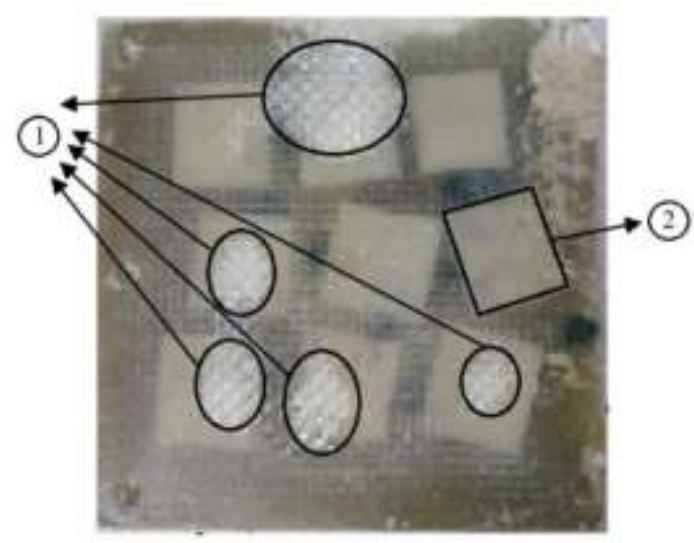

Source: Authors.

Small dry areas were identified due to flow block by the inserts (1) and that the inserts moved during processing (2), which was attributed to the changes made in inlet/outlet placement for plate processing.

In order to avoid insert movement, a different set-up for plate P05 processing was adopted. The flow was again rectilinear with 1 inlet and 3 outlet points. The entry and exit points were kept in different planes. The inlet was located at the base of the mold and the outlet points were located on the mold cover.

Figure 13 illustrates plate P05 after processing. Dry areas were identified on the surface of plate P05 due to flow blockage by the inserts (1). It became evident that the change in the flow was not effective in preventing insert movement during processing (2). 
Figure 13 - Movement of the inserts on plate P05 when inlet and outlet points were placed in different faces of the mold.

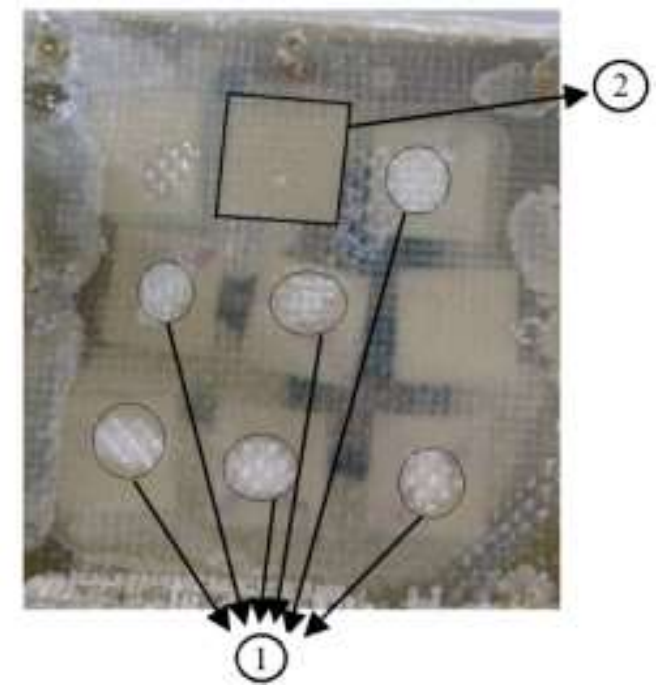

Source: Authors.

In order to prevent insert movement, the use of a fixation mesh was proposed (Figure 4c). Plate P06 was obtained by using a fixation mesh and keeping the same processing parameters used in plate P05. Figure 14 illustrates Plate P06 after processing.

Figure 14 - Final prototype plate 06.

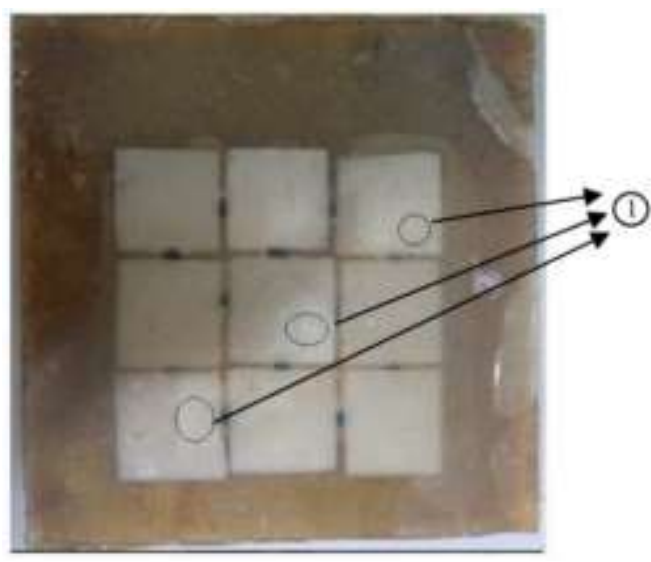

Source: Authors.

The use of the fixation screen was successful in preventing both insert movement and the formation of dry spots. Small dry areas were identified due to flow block by the inserts (1). This result was similar to that reported by Lawrence et al. (2007).

\section{Transversal Section Analysis of the Plates}

Figure 15 illustrates the thickness variation of plate P02. Variation of plate thickness is attributed to fiber compaction caused by vacuum pressure and by the presence of the insert. Thickness measurements were taken along the cross section of the plate (h1, h2, h3, h4 and h5). Average measurement results are illustrated in Figure 15b. 
Figure 15 - Transversal sections of plate P02. (a) places measured; (b) measurement values.

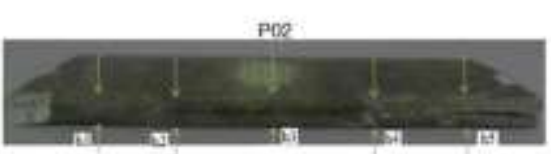

a)

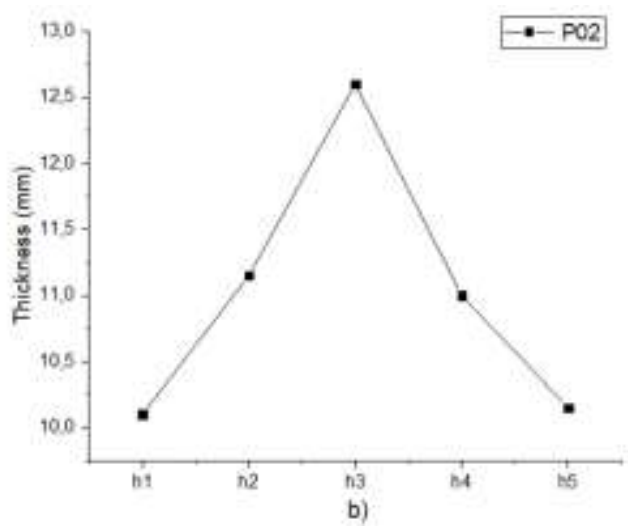

Source: Authors.

Figure $15 \mathrm{~b}$ shows that thickness varied along the plate, the center of the plate being thicker than the edges. This was expected as this plate has one 4mm HDPE insert placed at its center.

Figure 16 illustrates the thickness variation of plate P06. Cross-sectional measurements of plate P06 were performed to analyze possible variations in plate thickness during compaction (Figure 16a).

Figure 16 - Transversal sections of plate P06. (a) measurement places; (b) measurement results.
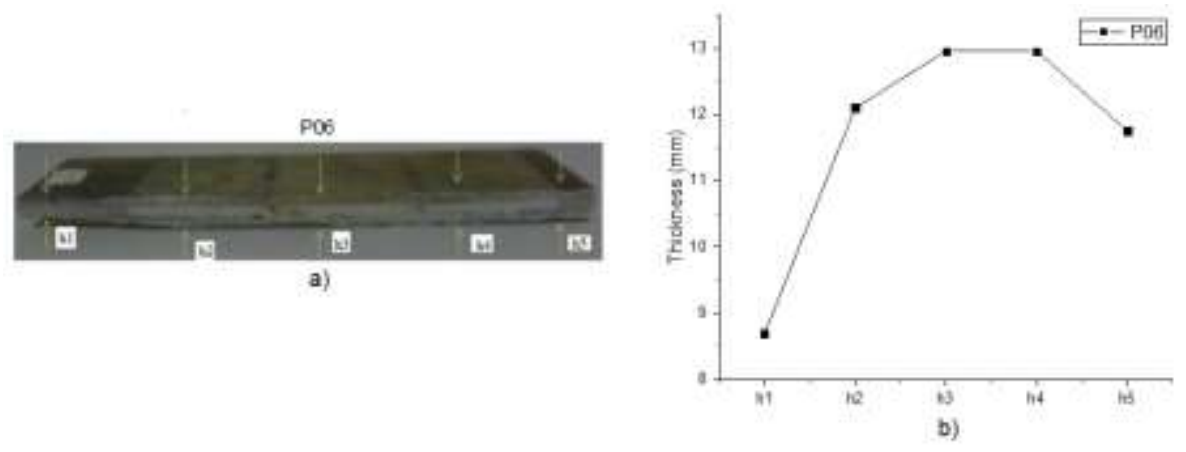

Source: Authors.

Figure 16b illustrates the average results of measurements made on the cross sections of plate P06 (h1, h2, h3, h4 and h5). It shows that, in the regions where there were inserts, there was little variation in plate thickness. In regions without inserts (h1 points), large variations in thickness were identified. Thus, the farther from an edge the inserts are positioned, the greater the effects of fiber compaction in that region.

The conclusions on our research about resin flow analysis during RTM manufacturing of composites containing embedded impermeable inserts are illustrated in Figure 17. Four zones were observed in the composites. Zone 1, located at the edges of the plate, is a region where the fibers have suffered little compaction. In zone 2 the fibers suffered bigger compaction effects due to the presence of the inserts and the use of vacuum pressure, generating resin-rich regions on the plate surfaces. In zone 3 fiber separation due to the presence of the inserts and formation of resin rich regions near the sides of the inserts is observed. Zone 4, where the insert is placed, is a zone where the fibers are subjected to great compression due the insert presence and vacuum pressure. Similar results were reported by Xiao et al. (2016), Lacasse et al. (2015), Simoneau et al. (2014) and Steeves et al. (2006) on systems with embedded devices. 
Figure 17 - Composite cross section with embedded insert.

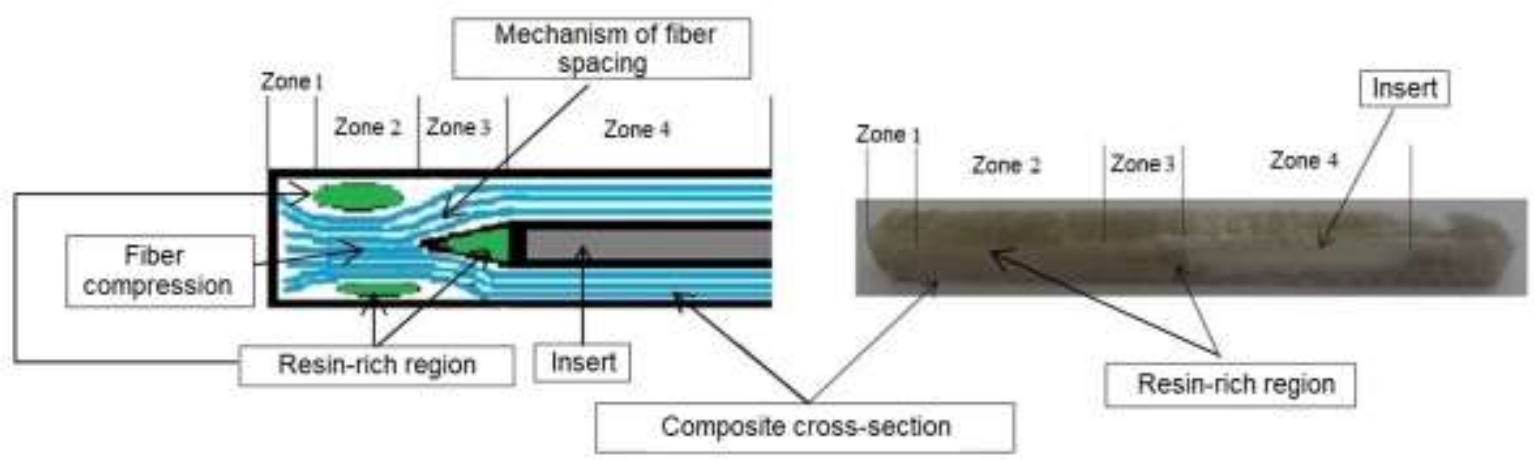

Source: Authors.

\section{Three-point Bending Tests}

Three-point bending tests were performed on the samples to analyze composite failure mode (Figure 18).

Figure 18 - Failure modes observed on a flexural tested sample with an embedded insert.

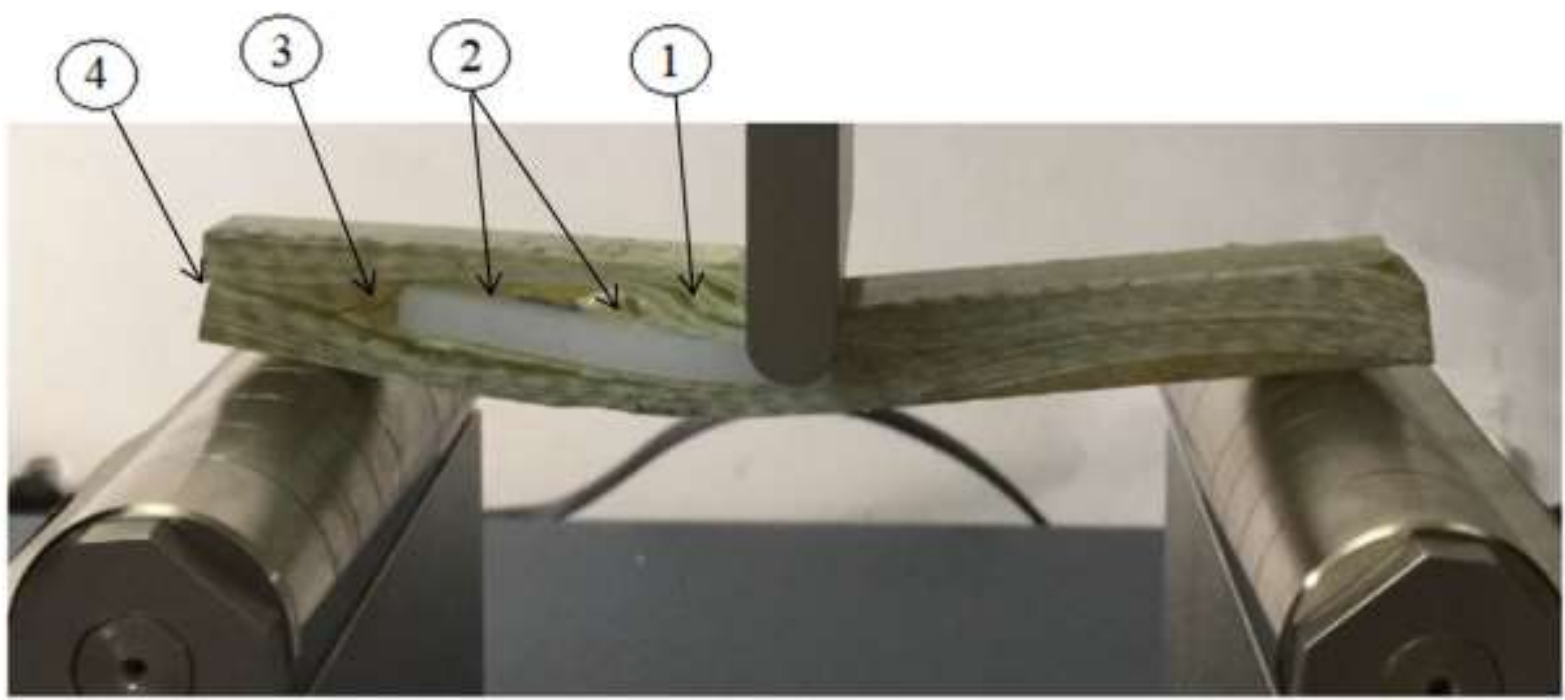

Source: Authors.

Four failure modes were identified: In (1) there was type II shear stress delamination (Mode II: in-plane shear) in the upper layers of the fibers. In (2) there was delamination between the fiber/matrix interface and the insert. In (3) there was fracture through the thickness of the resin-rich region formed by the spacing of the fibers. In (4) there was once again type II shear stress delamination with crack propagation from the resin-rich region to the edge of the specimen. This result is similar to that reported by Xiao et al. (2016).

\section{Conclusion}

The influence of impermeable inserts embedded during RTM processing of polyester/fiberglass composites was determined. During processing, resin flow took place from the edges to the center of the mold evidencing the difficulty of the resin to flow through the preform. Racetrack phenomenon was observed in the mold walls. The use of three outlet points on the P02 plate improved the resin flow during processing by improving the air removal from the mold when compared to the P01 
plate. Results indicate that the inserts block the cross-flow of resin leading to the formation of dry spots on the surface of the plate. A fixing screen, incorporated in plate P06, avoided insert movement. Composite cross-section shows four zones: Zone 1, located at the edges of the plate, is a region where the fibers are subjected to little compaction. In zone 2 , near the insert but not next to it, the fibers are more compacted, generating resin-rich regions on the board surfaces. In zone 3, near the insert wall, the fibers are spaced and a resin rich region appears near the sides of the inserts. Zone 4 is at the insert placement. Flexural testing yielded four types of composite failure modes: a) a type II shear stress delamination in the upper layers of the fibers; b) delamination between the fiber/matrix interface and the inserts; c) fracture through the thickness of the resin rich region; and d) type II shear stress delamination with crack propagation from the resin rich region to the edge of the specimen.

For future work, some suggestions would be: improve the processing of the composites by the single step method, use of ballistic ceramics as an insert, improve the adhesion between the GFRP composite and the inserts and perform ballistic tests on the composite plates.

\section{Acknowledgments}

The authors would like to thank CAPES and CNPq for financial support through fellowships for Aranha (D-Capes) and Carvalho (PQ-CNPq). The authors are indebted to LaMMEA - UFCG, NUTES - UEPB and the Stratus Aeronaves for laboratory support.

\section{References}

Agnes, E. A., \& Hilling, E. (2020). Propriedades físico-mecânicas de compósitos polímero-fibra produzido por moldagem prensada. Research, Society and Development, 9(8). http://dx.doi.org/10.33448/rsd-v9i8.5063.

Ahmed, A., Fahim, A., \& Naguib, H. E. (2010). Load bearing properties of three-component polymer composites. Polymer composites, 31 , $1731-1737$. https://doi.org/10.1002/pc.20963.

Ahmed, A., Fahim, A., \& Naguib, H. E. (2011). A study on the anchoring orientations of foam and sandwich composites with metal. Polymer Composites, 32, 596-603. https://doi.org/10.1002/pc.21070.

Amorim Jr., W. F. (2007). Processamento de placa espessa de compósito através de moldagem por transferência de resina. PhD thesis, Universidade Federal do Rio de Janeiro.

Aranha, R. (2017). Estudo do processamento de materiais compósitos com inserts impermeáveis embebidos via RTM. Master thesis, Universidade Federal de Campina Grande.

ASTM D7264/D7264M-15, Standard Test Method for Flexural Properties of Polymer Matrix Composite Materials, ASTM International, West Conshohocken, PA, 2015.

Batista, S. S., Souza, L. G. M., Bezerra, D. M. L., \& Neto, R. V. P. (2020). Viabilities for obtaining, manufacturing and applying composites using bamboo powders and ophthalmic lens waste. Research, Society and Development, 9(9). http://dx.doi.org/10.33448/rsd-v9i9.7455.

Chen, B., Lang, E. J., \& Chou, T.W. (2001). Experimental and theoretical studies of fabric compaction behavior in resin transfer molding. Materials Science and Engineering: A, 317, 188-196. https://doi.org/10.1016/S0921-5093(01)01175-3.

Chizari, K., Arjmand, M., Liu, Z., Sundararaj, U., \& Therriault, D. (2017). Three-dimensional printing of highly conductive polymer nanocomposites for emi shielding applications. Materials Today Communications, 11, 112-118. https://doi.org/10.1016/j.mtcomm.2017.02.006.

Etches, J. A., \& Fernando, G. F. (2009). Evaluation of embedded optical fiber sensors in composites: EFPI sensor fabrication and quasi-static evaluation. Polymer Composites, 30, 1265-1274. https://doi.org/10.1002/pc.20690.

Gauvin, R., Trochu, F., Lemenn, Y., \& Diallo, L. (1996). Permeability measurement and flow simulation through fiber reinforcement. Polymer composites, 17, 34-42. https://doi.org/10.1002/pc.10588.

Gebhardt, J., \& Fleischer, J. (2014). Experimental investigation and performance enhancement of inserts in composite parts. Procedia CIRP, 23 , 7-12. https://doi.org/10.1016/j.procir.2014.10.084.

Hammami, A., Gauvin, R., \& Trochu, F. (1998). Modeling the edge effect in liquid composites molding. Composites Part A: applied science and manufacturing, 29, 603-609. https://doi.org/10.1016/S1359-835X(97)00120-6.

Hanu, L., Simon, G., Mansouri, J., Burford, R., \& Cheng, Y. (2004). Development of polymer-ceramic composites for improved fire resistance. Journal of materials processing technology, 153, 401-407. https://doi.org/10.1016/j.jmatprotec.2004.04.104. 
Jhan, Y. T., Lee, Y. J., \& Chung, C. H. (2011). Resin flowing analysis in sandwich laminates under VARTM process. Journal of Reinforced Plastics and Composites, 30, 533-545. https://doi.org/10.1177/0731684411399142.

Kim, H., Myounggu, P., \& Hsieh, K. (2006). Fatigue fracture of embedded copper conductors in multifunctional composite structures. Composite Science and Technology, 66, 1010-1021. https://doi.org/10.1016/j.compscitech.2005.08.007.

Lacasse, S., Terriault, P., Simoneau, C., \& Brailovski, V. (2015). Design, manufacturing, and testing of an adaptive composite panel with embedded shape memory alloy actuators. Journal of Intelligent Material Systems and Structures, 26, 2055-2072. https://doi.org./10.1177/1045389X14549862.

Lawrence, J. M., Frey, P., Obaid, A. A., Yarlagadda, S., \& Advani, S. G. (2007). Simulation and Validation of Resin Flow During Manufacturing of Composite Panels Containing Embedded Impermeable Inserts with the VARTM Process. Polymer Composites, 28, 442-450. https://doi.org/10.1002/pc.20293.

Lee, C. H., Kim, C. W., Yang, S. U., \& Ku, B. M. (2007). A development of integral composite structure for the ramp of infantry fighting vehicle. $23^{\circ}$ International Symposis on Ballistics Tarragona.

Liu, B., Bickerton, S., \& Advani, S. G. (1996). Modelling and simulation of resin transfer moulding (rtm)-gate control, venting and dry spot prediction. Composites Part A: applied science and manufacturing, 27, 135-141. https://doi.org/10.1016/1359-835X(95)00012-Q.

Madhi, S. et al. (2003). Effect of the manufacturing process on the interfacial properties and structural perfomance of multi-functional composite structures. Composites Part A: applied science and manufacturing, 34, 635-647. https://doi.org/10.1016/S1359-835X(03)00091-5.

Naik, N. K., Rao, N., Agarwal, U., Raju, K. A., Pottigar, S. A., \& Suresh, V. (2009). Sandwich structures with composite inserts: experimental studies. Polymer Composites, 30, 639-648. https://doi.org/10.1002/pc.20600.

Obaid, A. A., \& Yarlagadda, S. (2008). Structural performance of the glass fiber-vinyl ester composites with interlaminar copper inserts. Composites: Part A: applied science and manufacturing, 39 195-203. https://doi.org/10.1016/j.compositesa.2007.11.006.

Pappada, S., Rametta, R., Largo, A., \& Maffezzoli, A. (2012). Low-velocity impact response in composite plates embedding shape memory alloy wires. Polymer Composites, 33, 655-664. https://doi.org/10.1002/pc.22170.

Simoneau, C., Terriault, P., Lacasse, S., \& Brailovski, V. (2014). Adaptive composite panel with embedded SMA actuators: modeling and validation. Mechanics Based Design of Structures and Machines, 42, 174-192. https://doi.org/10.1080/ 15397734.2013.864246.

Souza, N. S., Felipe, R. C. T. S., Felipe, R. N. B., \& Lima, N. L. P. (2020). Resíduos sólidos industriais: compósito com resíduos de plástico reforçado com fibra de vidro. Research, Society and Development, 9(9). http://dx.doi.org/10.33448/rsd-v9i9.7136.

Sozer, E., Simacek, P., \& Advani, S. (2012). Resin transfer molding (rtm) in polymer matrix composites. Manufacturing techniques for polymer matrix composites (PMCs), 245-309. https://doi.org/10.1533/9780857096258.3.243.

Steeves, C. A., \& Fleck, N. A. (2006). In-plane properties of composite laminates with through-thickness pin reinforcement. International Journal of Solids and Structures, 43, 3197-3212. https://doi.org/10.1016/j.ijsolstr.2005.05.017.

Thakur, A., \& Dong, X. (2020). Printing with 3D continuous carbon fiber multifunctional composites via UV-assisted coextrusion deposition. Manufacturing Letters, 24, 1-5. https://doi.org/10.1016/j.mfglet.2020.02.001.

Xiao, Y., Oiao, W., Fukuda, H., \& Hatta, H. (2016). The effect of embedded devices on structural integrity of composite laminates. Composites Structures, 153, 21-29. https://doi.org/10.1016/j.compstruct.2016.06.007.

Wang, Q., Chen, Z., \& Chen, Z. (2013). Design and characteristics of hybrid composite armor subjected to projectile impact. Materials and Design, 46, 634639. https://doi.org/10.1016/j.compstruct.2016.06.007.

Zhao, D. (2011). Study of a new manufacturing for multi-functional composite structures with aerosol-jet printing. Master thesis, Florida State University. 